\title{
A PHILOSOPHICAL APPROACH TO ARTIFICIAL INTELLIGENCE AND ISLAMIC VALUES
}

\author{
Ali A.Z. \\ International Institute of Islamic Thought and Civilization (ISTAC), \\ International Islamic University Malaysia, Kuala Lumpur Campus, \\ No. 24 Persiaran Duta Taman Duta, 50480 Kuala Lumpur,Malaysia.
}

aaziaee@hotmail.com

\begin{abstract}
Artificial Intelligence has the potential to empower humans through enhanced learning and performance. But if this potential is to be realized and accepted, the ethical aspects as well as the technical must be addressed. Many engineers claim that AI will be smarter than human brains, including scientific creativity, general wisdom and social skills, so we must consider it an important factor for making decisions in our social life and especially in our Islamic societies. The most important challenges will be the quality of representing the Islamic values like piety, obedience, Halal and Haram, and etc in the form of semantics. In this paper, I want to emphasize on the role of Divine Islamic values in the application of $\mathrm{AI}$ and discuss it according to philosophy of $\mathrm{AI}$ and Islamic perspective.
\end{abstract}

ABSTRAK: Kecerdasan buatan (AI) mempunyai potensi untuk memberi kuasa kepada manusia melalui proses pembelajaran dan prestasi yang dipertingkatkan. Jika potensi ini menjadi kenyataan dan diterima, aspek-aspek etika serta teknikal perlu ditangani. Ramai jurutera mendakwa bahawa AI akan menjadi lebih bijak daripada otak manusia, termasuk kreativiti saintifik, kebijaksanaan umum dan kemahiran sosial, jadi kita mesti menganggapnya sebagai satu faktor penting untuk membuat keputusan dalam kehidupan sosial kita dan terutama dalam masyarakat Islam. Cabaran-cabaran yang paling penting adalah apabila AI digunakan untuk menilai ciri-ciri Islam seperti ketakwaan, ketaatan, Halal dan Haram, dan lain-lain. Dalam kertas ini, saya ingin memberi penekanan kepada peranan nilai-nilai Islam dalam pengunaan AI yang dibahaskan mengikut falsafah AI dan perspektif Islam.

KEYWORDS: value; expert; community development; artificial intelligence; superintelligence; friendly artificial intelligence

\section{INTRODUCTION}

Artificial Intelligence is all around us. Intelligent agents are widely used. The physical embodiment of agents, robots, are also becoming more widely used. Robots are used to explore the oceans and other worlds, being able to travel in environments inhospitable to humans. It is still not the case, as was once predicted, that robots are widely used by households. Expert systems are used by doctors to help with symptoms that are hard to diagnose or to prescribe treatments in cases where even human experts have difficulty. Artificial Intelligence Systems are used in a wide rang of industries, from helping travel agents select suitable holidays to enabling factories to schedule machines. Artificial Intelligence is particularly useful in situation where traditional methods would be too slow. Many computer games have been designed based on Artificial Intelligence. It is likely that Artificial Intelligence will become more prevalent in our society. And whether 
or not we eventually create an Artificial Intelligence that is truly intelligent, we are likely to find computers, machines, and other objects appearing to become more intelligent- at least in terms of the way they behave [1].

Definitions: What are Artificial Intelligence, friendly AI, and Superintelligence? John McCarthy defines it as making intelligent machines especially intelligent computer programs by the science and engineering. It is related to the similar task of using computers to understand human intelligence, but AI does not have to confine itself to methods that are biologically observable [2]. AI is the area of computer science focusing on creating machines that can engage on behaviors that humans consider intelligent. Intelligent agents can plan and adapt plans to respond to changes in circumstances; they can recognize what is significant in a situation; they can learn new concepts from old; they can interact and learn from their environment; they can exercise artistic appreciation [3].

The ability to create intelligent machines has intrigued humans since ancient times and today with the advent of the computer and 50 years of research into AI programming techniques, the dream of smart machines is becoming a reality. Researchers are creating systems which can mimic human thought, understand speech, beat the best human chess player, and countless other feats never before possible. Find out how the military is applying AI logic to its hi-tech systems, and how in the near future Artificial Intelligence may impact our lives.

AI is a combination of computer science, physiology, and philosophy. AI is a broad topic, consisting of different fields, from machine vision to expert systems. The element that the fields of AI have in common is the creation of machines that can "think". In order to classify machines as "thinking", it is necessary to define intelligence. To what degree does intelligence consist of, for example, solving complex problems, or making generalizations and relationships? And what about perception and comprehension? Research into the areas of learning, of language, and of sensory perception have aided scientists in building intelligent machines.

One of the most challenging approaches facing experts is building systems that mimic the behavior of the human brain, made up of billions of neurons, and arguably the most complex matter in the universe.

\section{VALUES AND AI}

The process of developing active and sustainable communities based on social justice and mutual respect. It is about influencing power structures to remove the barriers that prevent people from participating in the issues that affect their lives. Community Development expresses values of fairness, equality, accountability, opportunity, choice, participation, mutuality, and continuous learning.

In future, we will not face a group of engineers who can program our social life in different fields such as reasoning, problem solving, knowledge representation, planning, learning, natural language processing, motion and manipulation, perception, social intelligence and creativity, but also we will face more complex expert systems such as superintelligence which will surpass all abilities of human being except the intentionality and spirituality as defined in our religious sources. If artificial intelligence claims that it is able to recreate the capabilities of the human mind, by the invention of superintelligence, with which challenges will we confront in the future? Should we be worry about our spiritual life, our divine values, emotions, piety, sincerity, belief, and our shari'ah? A few of the most influential answers to these questions are given below. 
In this century the information is a main power in society, and the experts who owes this opportunity can influence on the society, and I think in the future instead of human experts we will face expert system in Artificial Intelligence technology.

Human values or divine values, secularism or theism, expert system or human expert, it will be our challenge in future and I think we must give a high consideration to this problem for next decades. The new generation of computers will be able to do millions operations at a moment. Most AI work today does not require any philosophy, because the system being developed doesn't have to operate independently in the world and have a view of the world. The designer of the program does the philosophy in advance and builds a restricted representation into the program. We have been studying this issue of AI application for quite some time now and know all the terms and facts. But what we all really need to know is what we can represent human values in a formal manner. One conclusion from artificial intelligence research is that solving even apparently simple problems usually requires lots of knowledge. Properly understanding a single sentence requires extensive knowledge both of language and of the context. How can we represent the concept of fairness -in the human life as an important base for community development- in meaningful way for AI [4].

Knowledge of development is information about better social life for human and we can describe these terms and conditions by their properties. There are many ways to represent objects. These objects concern to development are complex objects and a complex object may be composed of many other objects. This is a kind of reductionism. The reductionism position is that the complex behavior of the mind may in principle be reduced to similar rules and laws which may be complex but which can be investigated and understood [13] Cultural development, economic development, scientific development, and finally community developments depend on many wide areas of human knowledge and values which are accepted with all human beings, but we must know that there is a big gap between secular values and divine values. Accepting the values at the level of common sense will result in secularism. Secular and liberal values, if we consider them as values, do not serve the interests of Muslim communities. How can we represent some concepts such as piety (taqwa), obedience of Allah (ta'ah), fear of God (khashiyyah), and etc? Engineers in computer science believe that all values will be presented in formal ways to be known by AI or Superintelligence and these new creations will influence on our life.

As we know AI works with fuzzy logic, approximate concepts, uncertainty and ambiguous data. If AI wants to have freewill it must work with uncertain concepts. With absolute data and information the freewill cannot exist in AI. Now we must ask the experts about our beliefs which based on certainty and absolute knowledge, what about Divine knowledge which is certain and absolute? Is AI can play a positive role in this sensitive field especially in our Islamic societies?

We should be prepared for a change. Our conservative ways stand in the way of progress. The most traditionalists consider the ummah's traditional thought to be selfsufficient and capable of being presented as it is or with very little alteration. This approach holds that the ummah's intellectual life can be founded and organized, and that the structure of its civilization can be built on this basis. We should find a way to select our strategies in absorbing new technologies from the traditional thought what is most sound and from modern contemporary thought that one considers and proves to be correct, and weld the two to found an intellectual structure, which will provide a guaranteed basis for achieving what is required [5]. 
In response to change, our vision to new technology and our mission of Higher Islamic Education in Muslim World needs to be revised. The wake of globalization is multi-dimensional in nature. AI is a new step that is very helpful to the society and its development. Machines can do jobs that require detailed instructions followed and mental alertness. AI with its learning capabilities can accomplish those tasks but only if the worlds conservatives are ready to change and allow this to be a possibility. I am not worry about how we can construct this powerful program which will be smarter than the best human brain, but I am worry about how we lead them to human values. I am worry about the worst of AI. There are so many things that can go wrong with a new system so we must be as prepared as we can be for this new technology. AIs are like children that need to be taught to be kind, well mannered, and intelligent. If they are to make important decisions, they should be wise. We as citizens need to make sure AI programmers are keeping things on the level. We should be sure they are doing the job correctly, so that no future accidents occur. AI is what Nick Bostrom calls an existential risk: "One where an adverse outcome would either annihilate Earth-originating intelligent life or permanently and drastically curtail its potential." In particular, most forms of unfriendly AI would constitute a "Bang"-"Earth-originating intelligent life goes extinct in relatively sudden disaster resulting from either an accident or a deliberate act of destruction." Within Nick Bostrom's list of Bangs, sorted by probability, "badly programmed Superintelligence" is number four out of eleven [6].

Artificial Intelligence, as an ultratechnology, does not exist in isolation. There are other kinds of advancing technologies; nanotechnology, biotechnology, and nuclear technology, for example. Artificial Intelligence is unique among the ultratechnologies in that it can be given a conscience, and in that successful development of Friendly AI will assist us in handling any future problems. A "Friendly AI" is an AI that takes actions that are, on the whole, beneficial to humans and humanity. In a " human" scenario ("near human", "approximately human-equivalent"), Friendly AIs would play human roles in the existing human economy or society. To the extent that Friendly AIs have power in the world economy, in human society, or in technological development, they can exert direct influence for good, but mostly in physical world not in spiritual realm such as values and ethics. In the Islamic tradition, technology is always tools not goals. Human values and ethics should become the guiding principles in utilizing technologies so that the usage of technology is more humane and having beneficial advantages to humanity. For example, a Friendly AI working in nanotechnology can enthusiastically work on Immunity systems while flatly refusing to develop nanotechnological weaponry. The presence of Friendly AIs within a society -as an interest group with influence- will tend to influence that society towards altruism.

The presence of a Friendly AI within a political discussion - as a voice advocating a viewpoint - will tend to influence that discussion towards lack of bias. This holds especially true insofar if Friendly AIs have previously gained respect as fair, truthful, unbiased voices.

The presence of a Friendly AI within a political power structure - as a decision-maker - will lead to altruistic decisions being made. This holds especially true insofar if decisions which humans keep screwing up due to personal bias tend to get handed off to a Friendly AI.

The presence of a Friendly AI within a technological development process -as a researcher- will tend to accelerat defensive applications and economic applications ahead 
of offensive applications, and largely beneficial technologies ahead of more ambiguous ones.

The requirements for FAI to be effective, both internally, to protect humanity against unintended consequences of the AI in question and externally to protect against other nonFAIs arising from whatever source, are:

Friendliness: that an AI feel sympathetic towards community development in future, and seek for their best interests Conservation of Friendliness - that an AI must desire to pass on its value system to all of its offspring and inculcate its values into others of its kind.

Intelligence: that an AI be smart enough to see how it might engage in altruistic behavior to the greatest degree of equality, so that it is not kind to some but more cruel to others as a consequence, and to balance interests effectively.

Self-improvement: that an AI feel a sense of longing and striving for improvement both of itself and of all life as part of the consideration of wealth, while respecting and sympathizing with the informed choices of lesser intellects not to improve themselves. But there are authors who consider the theory of Friendly AI is incomplete. They believe that there should be broader political involvement in the design of AI and AI morality and this will has a bad influence on community development. They also believe that initially seed AI could only be created by powerful private sector interests [7].

\section{CONCLUSION}

Educating, enabling and empowering are at the core of Community Development. I think that community development is conscious social activity that contains the spiritual and material life of the society. We must give the high consideration to the role of human values, spiritual aspect of human being and his cultural and educational inquiries, and to the role of experts and community workers and politic leaders or officers in the community development. It demand the emergence of transformative leadership in leading transformative education for Muslim experts especially in managing change and challenges for better developments in our society. A holistic approach in nurturing experts with ethical values and morals is greatly needed in this century, because the rise of globalization with its structural impacts need to be balance up with a more equitable and harmonious approach in teaching and learning. Neglecting the importance of compatibility in responding to change, leadership in higher Islamic education in its present scope and orientation, and skillful Muslim experts with Islamic knowledge and better understanding of computer science may lead to the marginalization of the ummah. Islamic studies of today demands a new theoretical foundation to address not only the authentic or traditional approach in addressing traditional sources and also turath but also the modern factors in teaching-learning processes which are very contemporary in nature. The chart on the next page illustrates the relationship between these elements

If human create Supperintelligence in future - and I think it will be possible, because in this moment we can produce Distributed Artificial Intelligence which can process faster than human brain- our belief to that reality will not change, because we consider Supperintelligence as an effect of human mind and creativity and the law of causality proves that the existence of effect depends on the cause, so I believe that Superintelligence will not damage our life as we see in Hollywood films, but the values of human which organize our better intellectual life must be programmed in the future, and with this 
approach we can solve the challenge between Community Development and Supperintelligence, we can call it friendly Artificial Intelligence.

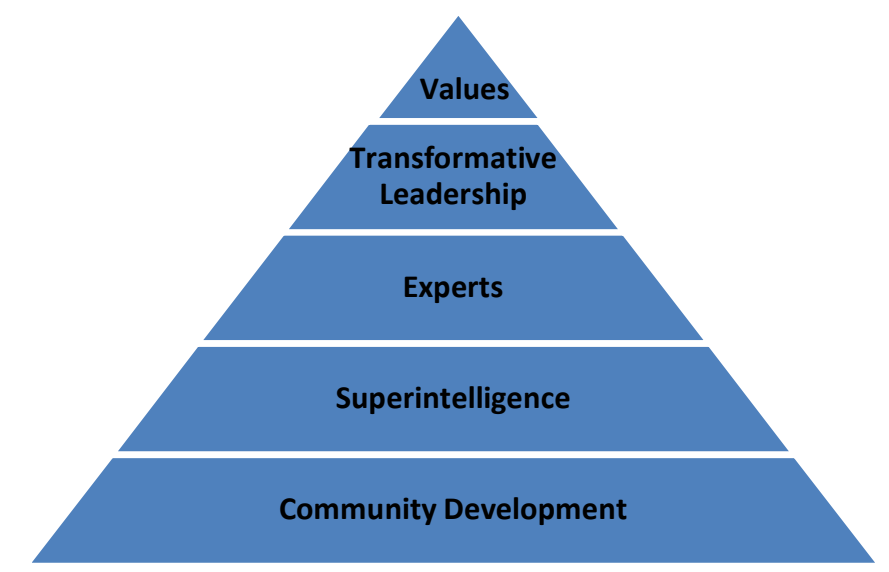

\section{REFERENCES}

[1] Ben Coppen, Artificial Intelligence illuminated, London, Jones And Bartelett Publication, 2004, pp. 23-24.

[2] John McCarthy, "What Is Artificial Intelligence?" Computer Science Department, Stanford University Stanford, CA 94305.

[3] Janet Finaly \& Alan Dix, Artificial Intelligence, UCL Press, 1996, p. 262,

[4] Nick Bostrom, "How Long Before Superintelligence?" in International. Journal. of Future Studies, 1998, vol. 2.

[5] Based on talks given in a Conference on the Conceptual Aspects of Biocommunications, Neuropsychiatric Institute, University of California, Los Angeles, October 1962; and in the Artificial Intelligence Sessions of the Winter General Meetings of the IEEE, January 1963.

[6] Based on the SCCD Strategic Framework, the National Occupational Standards for CD work, and the latest draft of CDX's Information Sheet: What is community development.

[7] Midgley, J. with Hall, A., Hardiman, M. and Narine, D. (1986), Community Participation, Social Development and the State, London: Methuen, p. 18.

[8] Alison Cawsey, The essence of Artificial Intelligence, England, Prentice Hall, 1998, p. 3.

[9] Morris W. Firebaugh, Artificial Intelligence, A Knowledge - based Approach, Boston, PWS-Kent Publishing Company, 1988, p.14.

[10] Nick Bostrom, "Existential Risks: Analyzing Human Extinction Scenarios and Related Hazards, in "Journal of Evolution and Technology, Vol. 9, March 2002. First version.

[11] ibid.

[12] Bill Hibbard, Super-Intelligent Machines, New York. Kluwer Academic/Plenum Publishers. 2002; Hibbard, W. Super-intelligent machines. Computer Graphics 35(1), 11-13. 2001.

[13] Morris W. Firebaugh, Artificial Intelligence, A Knowledge - based Approach, Boston, PWS-Kent Publishing Company, 1988, p.14. 